ISBN 978-81-933894-1-6

International Conference on Arts, Social Sciences, History and Interdisciplinary Studies

(ASSHIS-2017)

Kyoto (Japan) April 20-21, 2017

\title{
Exit or Entry the Boundary- The Cause and Effect of Oppressed Religion during the Martial Law Period in Taiwan
}

\author{
Wang, Po-Hsien \\ National Chengchi University, Taiwan
}

\begin{abstract}
In the history of religion in Taiwan, the most direct impact is the martial law. If the religious has contrary to the government, it will actively suppress or ban them.

For example, in 1953, the Yiguandao was listed in illegal religion by the government. And even the Presbyterian Church in Taiwan (P.C.T.) which is not banned, have been persecuted by the government. However, all of them faced the pressure from the government, but the causes and results are completely different.Yiguandao not only continued their missionary work in Taiwan, but also began their overseas missionary work at that time. The tension between the P.C.T. and the government was from the linking to the international organizations just like the W.C.C. After that, some of the Taiwanese pastor in American develop Local Theology. The entry and exit of the two religions shows the maritime nature of Taiwan religionThis study constructs the relationship between Taiwan's internal affairs, international situation and the development of religion. The following preliminary results are obtained:

(1) The reason of the tension between government can classified into international or internal factor, but the real factor is "rule of man."

(2) The government's pressure makes Yiguandao into a gray or black market, creating a high commitment and driving force of output.

(3) The P.C.T. is highly organized, but because of the Presbyterianism makes the separation of the pastor in the presbytery and layer in the local church. It does not show the obvious religious market phenomenon.
\end{abstract}

Keywords: Presbyterian Church in Taiwan (P.C.T., 台灣基督長老教會)), Yiguandao(一貫道), The martial law regime of Taiwan, Religious economic theory

\section{Introduction}

Religion is a popular cultural phenomenon in human society. But the study of the influence of religion on politics has always been a taboo. But, after the two books, "The Clash of Civilizations and the Remaking of World Order" and "The Third Wave of Democratization" of S. P. Huntington has published, they make the reach of the interaction between religion, politics and society a big issue. Most of all, the tension between politics and religion in the Western history has been a very troubled problem. Many studies can find that religion plays an important role in politics.

Religion has a deep public base in Taiwan, showing a strong religious atmosphere in the common people's It with the flow of ethnicity, the form of religious religion in Taiwan is quite diverse and complex. Throughout the modern religion-state relations in Taiwan which has turned from a traditional government-regulated society into a free and equal society. However, such a change is not made overnight.

The religions develop in Taiwan has a certain degree of impact from the political intervention. But, the most direct impact on church-state relations is the martial law and the authoritarian regime. Since the Kuomintang(KMT, Chinese Nationalist Party, 國民黨) government came to Taiwan, The martial law and the authoritarian regime let the KMT can "control the religion". Whether it is Chinese religion or Western religion, if the religious has manifestly contrary to the policy of the government, KMT will actively suppress them 
through the district system, or banned it. And to the religions with Strong independence thinking, the KMT government will have strengthened control with them.

In 1953, Chinese religion Yiguandao was banned by the Ministry of Interior by the reason "adverse folk custom" as an evil cult. And even the unbanned religion like the Presbyterian Church in Taiwan (P.C.T. ,台灣基 督長老教會) was also persecuted by various reasons. However, despite its face the same government persecution, but the cause and effect was totally different, has a completely different meaning and context of the times. In this study, through the historical documents textual criticism, and with the concept of the religious market theory, the researcher will discuss the reasons and results of two religious which is persecuted by politics.

\section{Methodology}

To explain the mechanism of the cause and result of the change of political and religious relations in modern society, Researchers will use the Religious Economy Model as a method.

The traditional theory model regards the religion as a rigid body. With the advent of rationalism, humanism and the Industrial Revolution, it's impact on the human world leads to the change of human need (demand) for religion. The need of religion will be gradually reduced, and religion will die with the path of modernization. But this theory model is very different from the human life in the twentieth century; it cannot explain the development of the contemporary world religions such as the American evangelical revival in 20th century.

The religious economic theory provides another way to explain the role of religion in contemporary society from the view of religious organizations (supplier). Under the system of religious freedom competition, the theoretical model considers that religious practitioners based on the existence and development needs will continue to create and provide with new religious products to attract or even inspire the popular demand. thus it will contribute to the prosperity of religion. This study uses this new model as analyses model.

\section{The Politic-Religion Relations of P. C. T. and Yiguandao}

Presbyterian Church in Taiwan as the oldest missionary in Taiwan's, since Dr. Mackay, Canada, the United Kingdom's doctor Maxwell come to Taiwan, over 150 years. P.C.T. in the development of political and religious relations has always been standing on the role of interacting with the regime actively. The highest point of tension was in the aforesaid third period, the KMT government of Taiwan during the regime of Chiang Kai-shek. In the study of Lin Ben Hyun, we can found P.C.T. has issued three statements since the 1970s. ("Statement on our National Fate by the Presbyterian Church in Taiwan" On December 29, 1971; "Our Appeal by the Presbyterian Church in Taiwan" On November 18, 1975; "A Declaration on Human Rights by the Presbyterian Church in Taiwan” On August 16, 1977.) They solemnly demonstrated the P.C.T.'s pursuit of Taiwan's political reform and national independence. The Chiang regime confiscated the Bible, arrested preacher and sent spies to the church to monitor and continuously check the P.C.T..

On the other hand, " Yiguandao " is a "new religion." The most well-known cases of the suppression of the indigenous religion by the party and state system were the "Difficult(教難)". In 1953, it was banned by the Ministry of Interior by the reason "adverse folk custom" as an evil cult. Yiguandao was accused as "Ducks Egg Religion" and obscene religion. In 1963, the public security units vigorously banned Yiguandao. It's lead the group leaders announced to dissolute the groups in 1963.In 1964, the Taoist Church of Taiwan Provincial called the Yiguandao returned back to Taoism by the newspaper. It made many of the temple of Yiguandao had joined the Taoist Church. It is worth noting that the persecutors are mainly from Taiwanese system, the persecution on Chinese system is not active.

After a few years after the lifting of the martial law, After the efforts of the representative, Yiguandao was finally to lift the ban in 1987. 


\section{The Opposite Development of the two Religions}

The best way to understand the development of religion is to understand the change in the number of believers and the proportion of the total population. Taiwan with a total population of about 23 million, of whom the largest proportion believe in Buddhist beliefs, about 35\% of people consider themselves Buddhists, and Taoists for about $33 \%$. Yiguandao officially believers are about 1 million, it is the third largest religion after Taoism, Buddhism. About 4\% of all consider themselves Christians, approximately 300,000 Catholics; Protestants about 590,000, and the largest Protestant church is P.C.T., about 230,000 believers. However, the number of Yiguandao believers in the early years was controversial. Because it is an illegal religion before it lifting of the ban, so there is no formal statistics.

After banned in 1952, Yiguandao made a series of adjustments in Taiwan. In fact, the suppression from Kuomintang regime has reduced the number of "Free rider"those who only want the benefits and do not want to contribute in Yiguandao. The sacrifices of the devout believer leaders reinforce the confidence of other believers in the Yiguandao.

As a result, the illegal Yiguandao. has developed rapidly. In 1963, the number of believers develop to 50,000, in 1984 more than 320,000, In 1989, the Taiwan Social Change Questionnaire showed that 2.2\% of the population of Taiwan are believe in Yiguandao, that is, 440,000 believers. So far they have claimed that the number of believers has reached about one million people.

Unlike the Yiguandao, although P.C.T. had conflict with the government, it has never been prohibited by the government or classified as cult. Is the opposite situation leading a totally different development of the two religions?

Taiwanese Christians were around 70,000 in 1950. A short period of 14 years (1964), the total growth to nearly 28 million people, an increase of 210,000 people, grew up 3 times in only 14 years. P.C.T. has traditionally attributed this growth to the Double Church Movement (Poe Ka Un-tong, PKU) (1953-1962). However, Professor Qu Hai-yuan has pointed out that the growth of Presbyterian Church was consistent with the growth of environment, it cannot be completely attributed to the missionary movement performed by the P.C.T.. Professor Zhao Xing-guang also pointed out that the development of Christianity in the 1950s and 1960s was largely due to the political and social factors. These factors include the unstable situation in Taiwan, a large number of immigrants from other provinces, the United States material assistance and wondrous attitude.

Even after 1965 the Christian Church in Taiwan had entered a period of stagnation, from 1965 to 1970, the number of Christians in Taiwan increased about 80,000, but the rate of growth has been unable to catch up with the average rate of increase in the population of Taiwan. Only independent sects -True Jesus Church and the local church are still continuing to grow. The growth of rest of the churches were stagnant, even some of the number of believers has negative growth. Zhao Xing-guang attributed it to population migration and economic development to reduce religious demand, or the conflict Christian religious doctrine and the local culture, or other factors.

Such data seems to show the P.C.T. and Yiguandao have completely different fate.

\section{The Cause and Effect: Exit or Entry the Boundary}

Yiguandao was not only continuous deep plowing in Taiwan, but also did a series of adjustments. On the doctrine, they interpreted the government's banned policy as "official test"; In the organization, Vertical leadership adopted to reduce spread of the range when it is banned; At the same time to encourage missionary, who was successes can be promoted as " Master " can set up another portal.

Since then, various organizations began overseas missionary. Especially after the 1970s, with the rapid development of Taiwan's economy, Yiguandao has more economic strength to expand outward, and expand to the overseas. So far, Yiguandao has been widely exist in the world more than 80 countries and regions. It has become the most international Chinese-based faith entities. 
The tension between the Presbyterian Church and the government is made up of links with international organizations. In the 1950s the world was in a state of cold war, and the Western Church launched a ecumenism movement. In 1948, it establish the World Council of Churches(WCC). After that, Catholicism and Christianity jointly called for " church unity, world unity, human unity". They hope that this goal can make more dialogue with other religions, Marx communists, to term the opposition in history, and take joint action. But also because of the position of WCC, it accepted the socialist countries, and advocated recognition of the People's Republic of China. It's leading to the conflict between P.C.T. and the Kuomintang regime in Taiwan. At that time Taiwan Christianity divided into two camps, nominally, it is the conflict of doctrine, in fact, it is the dispute of political ideology. P.C.T. was forced to retreat to the WCC, although later it can return, but the opposition between the two camps is continuing to today.

At the same time, several Taiwanese pastors and Christians abroad developed the path of indigenous theology. In 1965, Dr. Shoki Coe, bishop Tu Tu, pastor Aharon Sapsezian according to the political, economic and social situation of the different regions, especially the third world, make recommendations on the future direction of theological education. To replace the term "customization" with the term "contextualization". In the <Ministry in Context: The Third Mandate Program of the Theological Education Fund (1970 1977) which was published in 1972,

This "Contextualization Theology" great influence of the Christian world. It not only affects the theological direction of the universal church after 1970, Such as the liberation theology of Latin America, American femininity and black theology. In the early 1970s, in order to promote the orientation of theology Education in Asia, the Southeast Asian Institute of Theological has organized a series of Asian theological seminars in Asian countries to try to stimulate the development of theology and theological education in Asia. The meeting of this series in Taiwan was held in Hsinchu. It the meeting, Taiwan's theologians proposed two possible themes for the development of theology in Taiwan, "Native land" and " Breakthrough Day 出頭天" This is the beginning of the development of native theology and the Breakthrough Day theology.

In 1972, Dr. Shoki Coe(黃彰輝), Dr. Huang Wu-dong(黃武東), Dr. Choan-Seng Song(宋泉盛) and Lin Zong-yi() initiated "Formosans for Self- Determination" in the United States They try to arouse the conscious awareness and self-determination of the people of Taiwan, and expressed the support for the "Declaration of Human Rights" which was published by the P.C.T., hoping that Taiwan could become a "new and independent" country. This makes mutual distrust increased with the government.

"Entry and exit" of the reason and result of the two religions' interfered by the government shows the characteristics of Taiwan's religion.

\section{Conclusions}

This study constructs the relationship between Taiwan's internal affairs and international situation and the development of religion with historical documents, from the National Government to Taiwan to the lifting of martial law. It has the following preliminary results:

\subsection{The Reason of the Tension Between Government can Classified into International or Internal Factor, But the Real Factor is "Rule Of Man."}

After Professor Dong Fang-yuan collated the file of Banned Yiguandao found that, the object of persecution is mainly based on the believers of Taiwanese, at the meantime, the believers of Chinese nationality are not active. And in the process of legalization of Yiguandao., Mr. Zhang Pei-cheng use of his position as president of the Republic of China Taoist Association. Writing a loyalty letter to the current president of Chiang Ching-kuo has mentioned:" Either in Taiwanese nor in mainland people, there is no any gap from the geographical and provincial. "He tries to joint provincial and other provinces to prove his loyalty. At the same time, Yiguandao use variety of ways to please the regime, to create relations with government, please the authorities and supervisors deliberately. Fully involved in the election, to vote for the ruling Kuomintang. To won the media 
sympathy, to create public opinion support. Most importantly to develop loyalists in the ruling party, to play an important role at the key moment.

The Kuomintang authorities were ruled by rule of law rather than the rule of law in the course of the prohibited the Yiguandao. On Christian side, it is clear to see in the process of P.C.T. in the establishment of Tunghai University, was forced out after it.

In 1953, the Christian University Preparatory Committee was composed by three groups of members: Foreign representatives (representatives of joint board of directors), Church representatives (mainly from Presbyterian Church), Government representative (representative of party and government with Christian background). The process of setting up is difficult and may not be successful. It' s until asked Song Mei-ling(宋 美齡, wife of Chiang Kai-shek) for the government lobby was finally allowed to set up the university.

And the important promoter is Dr. Shoki Coe, Huang Wu Dong and Dan Beeby, P.C.T. played an important role in it. However, the PartyInstitutionalization of Tunghai University began at who is the first president of the school, Joint Board of Directors invited Chen Xi-en(陳錫恩) as the first president of the school. Although Chen Xien has said that he will not serve as president for many times, but the opponents still attack him "not complete anti-Communist."

The party system put pressure on the representatives of the P.C.T. which has membership WCC. It's Leading the P.C.T. to withdraw from the joint board of the Tunghai University. Tunghai University since the establishment is very controversial, full of some ideological wrestling.

\subsection{The Government's Coercion Makes Religion a Black Market, it Creates a High Degree of Commitment to Become the Driving Force of Output.}

In 1963, the public security units vigorously banned Yiguandao, but the Yiguandao has not gradually disappeared. As Lu Yung-feng's analysis, because of the government' s suppressions, it reduces of free riders, and produce a greater number of faithful believers. On the other hand, the researcher also found that in the 1960s, Yiguandao has produced a large number of outward output. On the one hand, Yiguandao in Taiwan's is stabilized in its income, , and on the other hand, Yiguandao is moved abroad with immigrants.

In contrast to this, although because of the three major declarations issued, P.C.T. has a great friction with Kuomintang regime. However, the P.C.T. has never been banned. Thus, this makes the religious clerics become lazy, and also makes the vulgar lazy too. They take the religion compensation as free. Although there is PKU, the new century gospel movement, etc., but the P.C.T.' s mission works are much more conservative and single.

\subsection{The P.C.T. is Highly Organized, But Because of the Presbyterianism Makes the Separation of the Pastor in the Presbytery and Layer in the Local Church. It Does Not Show the Obvious Religious Market Phenomenon.}

The " Presbyterian " in the title "Presbyterian Church in Taiwan" shows two meanings, one refers to the church organization is " Presbytery" Second, it points out that the organizational structure emphasizes "the presbytery council". The churches are composed of pastor and elders, and it is the highest administrative institutions of the local churches. All the important affairs in the church are subordinate.

However, whether the resolution of the General Assembly will be implemented, or even the resolution of the General Assembly can be implemented in every local church of P.C.T. is an interesting topic. Using the three major statements of P.C.T. as an example, from the Northern Synod to the local Church have some object opinion and even expressed friendly action to the authorities. There are also many local churches that have not read out the statements because of political pressure.It can cause the upper layer had a serious dispute with the government, but the local church is isolated by the system of P.C.T.. Therefore, it did not form a strong belief as Yiguandao, reducing the free rider. 


\section{References}

[1] Finke, Roger (1997). The Consequences of Religious Competition: Supply-side Explanations of Religious Change. In Lawrence Young (Ed.), Rational Choice Theory and Religion: Summary and Assessment. New York: Routledge.

[2] Moyser, George 1991 "Politics and Religion in the Modern World: An Overview."PP.1-27 in George Moyser (ed.) , Politics and Religion in the Modern World.London: Routledge.

[3] Somerville, C. J. (1998). Secular Society Religious Population: Our Tacit Rules for Using the Term Secularization. Journal for the Scientific Study of Religion, 37(2).

https://doi.org/10.2307/1387524

[4] Stark, Rodney (1997). Bringing Theory Back In. In Lawrence A.Young (Ed.), Rational Choice Theory and Religion: Summary and Assessment. New York: Routledge.

[5] Warner, R. Steven (1993). Work in Progress toward a New Paradigm for the Sociological Study of Religion in the United States. American Journal of Sociology, 98(5).

https://doi.org/10.1086/230139

[6] 台灣基督長老教會 總會教育委員會《新編焚而不毀台灣基督長老教會信徒訓練手冊》(台北, 使徒出版社 2005)。

[7] 林本炫（1999）。台灣的政教衝突。臺北市：稻鄉。

[8] 曾慶豹（2017）。約瑟和他的兄弟們——護教反共、黨國基督徒與臺灣基要派的形成。台南, 台灣教會公 報社。

[9]＼cjkstart翟海源（1992）。重修台灣省通志卷 3 住民志宗教篇 1。台北市：國史館台灣文獻館。

[10] 篗海源（1996）。查禁與解禁一貫道的政治過。載於蕭新煌、徐正光（主編）, 台灣的國家與社會。台北: 東 大圖書。

[11] 瞿海源、姚麗香（1986）。台灣地區宗教變遷之探討。載於瞿海源、章英華（主編），台灣社會文化變遷。台 北市: 中央研究院民族學研究所。 